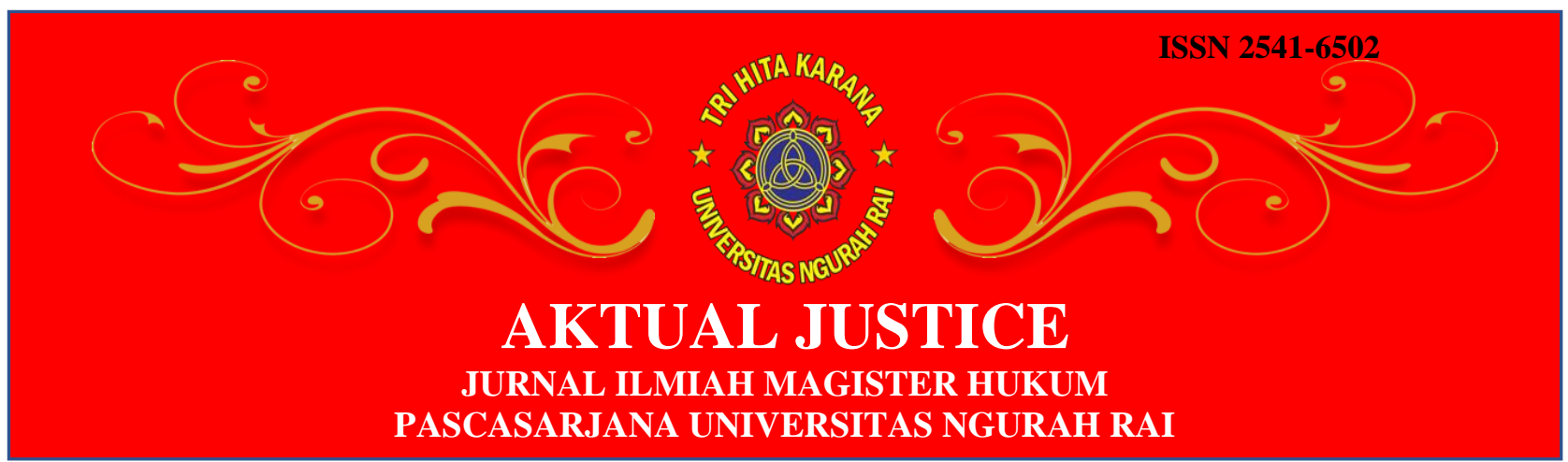

\title{
HUKUM WARIS DAN KEBUTUHAN BISNIS DALAM WARIS
}

\author{
Nisa P. Basti', Sanggup L Agustian², Sekar Wiji Rahayu ${ }^{3}$ \\ 1 Program Studi Hukum Bisnis Universitas Agung Podomoro, \\ Email : nisapermatabasti@gmail.com \\ 2Program Studi Hukum Bisnis Universitas Agung Podomoro, \\ Email :sanggup.agustian@podomorouniversity.ac.id \\ ${ }_{3}^{3}$ Program Studi Hukum Bisnis Universitas Agung Podomoro, \\ Email: sekar.wiji@podomorouniversity.ac.id
}

\begin{abstract}
There are many branches of law related to business law, including Corporate Law, Insurance Law, Banking Law, Inheritance Law, Commercial Law, and so on. The three systems of inheritance law have different perspectives in determining who is the heir, as well as other matters concerning inheritance. This will be explained in the next chapter. The issue of inheritance law always has its own challenges in every case. Starting from the ones that are easy to handle to cases that cause minor wars between families, sometimes even lawyers seek profit from this inheritance law case.

Keywords: inheritance, business
\end{abstract}

\footnotetext{
Abstrak

Banyak sekali cabang ilmu hukum yang berkaitan dengan hukum bisnis, diantaranya adalah Hukum Perusahaan, Hukum Asuransi, Hukum Perbankan, Hukum Waris, Hukum Dagang, dan lain sebagainya. Ketiga sistem hukum kewarisan ini memiliki cara pandang yang berbeda dalam menentukan siapa yang menjadi ahli waris, dan juga hal-hal yang mengatur mengenai kewarisan lainnya. Mengenai hal tersebut akan dijelaskan di bab selanjutnya. Permasalahan mengenai hukum kewarisan ini selalu saja memiliki tantangannya sendiri di dalam setiap kasusnya. Mulai dari yang mudah ditangani hingga kasus yang sampai meninmbulkan peperangan kecil diantara keluarga, bahkan kadang ada pula para lawyer yang mencari keuntungan dari kasus hukum waris ini.

Kata kunci: waris, bisnis
} 


\section{Pendahuluan}

Banyak sekali cabang ilmu hukum yang berkaitan dengan hukum bisnis, diantaranya adalah Hukum Perusahaan, Hukum Asuransi, Hukum Perbankan, Hukum Waris, Hukum Dagang, dan lain sebagainya. Dari sekian banyak cabang ilmu hukum bisnis, dalam penulisan ini saya akan membahas mengenai hukum kewarisan yang berlaku di Indonesia. Di Indonesia saat ini hukum waris diatur oleh 3 sistem kewarisan, diantaranya:

1. Hukum Kewarisan Perdata

2. Hukum Kewarisan Islam

3. Hukum Kewarisan Adat

Pada hakikatnya hubungan antara hukum kewarisan dengan kehidupan manusia sangatlah erat kaitannya. Sebab, dalam kehidupannya, setiap manusia pasti memiliki harta kekayaan semasa hidupnya. Baik itu berupa hak dan kewajiban, bernilai uang ataupun tidak. Ketika sang pemilik harta kekayaan tersebut meninggal dunia, maka haruslah ada hukum yang mengatur tentang siapa yang berhak menjadi penerus untuk menerima harta kekayaan yang ditinggalkan oleh sang pemilik harta tersebut.

Pengertian dari hukum waris adalah peraturan hukum yang mengatur perpindahan harta kekayaan dari pewaris kepada ahli waris. 1 Dalam hal ini yang berpindah adalah kekayaan si pewaris berupa hak dan kewajiban dan mempunyai nilai uang. ${ }^{2}$ Pewaris adalah seseorang yang meninggal dunia, baik laki-laki maupun perempuan yang meninggalkan sejumlah harta kekayaan baik berupa hak maupun kewajiban yang harus dilaksanakan selama hidupnya, baik dengan surat wasiat maupun tanpa

\footnotetext{
${ }^{1}$ Suparman,M. (2015). Hukum Waris Perdata. Jakarta: Sinar Grafika. h.10
}

${ }^{2}$ Ibid. 
surat wasiat. ${ }^{3}$ Sedangkan pengertian dari ahli waris adalah orang yang berhak menerima pusaka (peninggalan orang yang telah meninggal dunia). Ahli waris, yaitu sekalian orang yang menjadi waris, berarti orang-orang yang berhak menerima harta peninggalan pewaris. ${ }^{4}$ Mengenai hukum kewarisan yang sampai saat ini berlaku di Indonesia yaitu :

1. Sistem Hukum Kewarisan Perdata yang tertuang dalam Bulgelijk Wetboek atau KUH Perdata.

2. Sitem Hukum Kewarisan Adat.

3. Sitem Hukum Kewarisan Islam.

Dari banyaknya Sistem Hukum Kewarisan yang berlaku di Indonesia saat ini, sudah bisa dipastikan bahwa dibutuhkan ketelitian dalam menyelesaikannya, terutama dalam menentukan siapa yang menjadi ahli waris yang sah menurut wasiat atau menurut hukum yang berlaku. Sebab, dari setiap Sistem Hukum yang berlaku tersebut memiliki aturannya masing-masing dalam menentukan ahli waris yang sah dan pembagian harta warisan tersebut kepada setiap ahli waris yang ada.

Dimana ketiga sistem hukum kewarisan ini saling berkesinambungan satu sama lain, terutama antara Hukum Kewarisan Perdata dan Hukum Adat, Hukum Kewarisan Islam dan Hukum Adat. Ketiga sistem hukum kewarisan ini memiliki cara pandang yang berbeda dalam menentukan siapa yang menjadi ahli waris, dan juga hal-hal yang mengatur mengenai kewarisan lainnya. Mengenai hal tersebut akan dijelaskan di bab selanjutnya.

Pemilihan cabang ilmu hukum ini karena saya memiliki ketertarikan tersendiri dengan hukum waris. Saya seperti melihat tantangan dan petualangan yang akan saya dapatkan di dalam hukum

${ }^{3}$ Suparman, M. (2005). Hukum Waris Indonesia dalam Perspekstif Islam, Adat dan BW. Bandung: Refika Aditama, h. 28-29.

${ }^{4}$ Ibid., h. 2. 
waris ini sedikit berbeda dengan cabang ilmu hukum lainnya. Kesulitan yang ditawarkan pun justru menjadi tantangan tersendiri untuk saya mempelajari hukum waris ini lebih dalam lagi. Mengenai ilmu hukum waris ini memang belum disampaikan materinya di semester satu perkuliahan Jurusan Hukum Bisnis. Namun hal tersebut tidak menyurutkan keinginan saya untuk membahas sedikit hal-hal yang telah saya pelajari mengenai hukum kewarisan.

\section{Metode Penelitian}

Tulisan ini menggunakan metode penelitian yuridis normatif atau penelitian hukum normatif. Penelitian normatif adalah "Penelitian Hukum Normatif merupakan penelitian hukum yang dilakukan dengan cara meneliti bahan pustaka atau data sekunder". 5 "Penelitian hukum normatif disebut juga penelitian hukum doktrinal. Menurut Peter Mahmud Marzuki, penelitian hukum normatif adalah suatu proses untuk menemukan suatu aturan hukum, prinsip-prinsip hukum, maupun doktrin-doktrin hukum guna menjawab isu hukum yang dihadapi". 6

\section{Hasil Dan Pembahasan}

\section{a. Ahli Waris dan Pembagian Harta Warisan}

Dalam sistem hukum kewarisan perdata dalam menentukan ahli waris dibagi menjadi 4 golongan yaitu :

Ahli Waris Golongan I

a. Keluarga dalam garis lurus ke bawah, yaitu anak-anak atau keturunannya, tanpa membedakan jenis kelamin. Sebagaimana diatur dalam Pasal 852 di mana bagian mereka sama besar. ${ }^{7}$

${ }^{5}$ Soekanto, S. \& Mamudji, S. (2003). Penelitian Hukum Normatif : Suatu Tinjauan Singkat. Jakarta: Raja Grafindo Persada, h. 13.

${ }^{6}$ Marzuki, P.M. (2010). Penelitian Hukum, Jakarta: Kencana Prenada. h. 35

${ }^{7}$ Suparman, M. op.cit, h. 26. 
b. Suami atau istri yang ditinggalkan pewaris yang hidup paling lama. Dalam hal ini pembagian suami atau istri dari perkawinan pertama sama besar dengan bagian anak, kecuali suami atau istri dari perkawinan kedua, yang mendapat bagian paling maksimal adalah $1 / 4$ bagian dari harta warisan atau tidak boleh melebihi bagian anak yang terkecil. ${ }^{8}$ Seperti yang diatur dalam Pasal 852 KUH Perdata, yang berbunyi “ Anakanak atau sekalian keturunan mereka walaupun dilahirkan dari lain-lain perkawinan, mewaris dan kedua orang tua, kakek, nenek atau semua keluarga sedarah mereka dalam garis lurus ke atas, dengan tiada perbedaan antara lakilaki dan perempuandan tiada perbedaan berdasarkan kelahiran lebih dahulu. Mereka mewaris kepala demi kepala, jika dengan si meninggal (pewaris) mereka bertalian keluarga dalam derajat kesatu dan masing-masing mempunyai hak karena diri sendiri, mereka mewaris pancang demi pancang, jika mereka semua atau sebagian dari mereka bertindak sebagai pengganti."

c. Anak luar kawin yang diakui sah yang mendapat bagian tidak sama dengan anak sah. ${ }^{9}$

Ahli Waris Golongan II

Keluarga dalam garis lurus ke atas. Jika tidak ada suami atau istri dan keturunannya, maka warisan jatuh kepada keluarga sedarah golongan kedua. Untuk urusan pembagian warisan, hal tersebut telah diatur dala Pasal 854,857, dan 859 KUH Perdata.

"Bila seseorang meninggal dunia tanpa meninggalkan keturunan dan suami atau isteri, maka bapaknya atau ibunya yang masih hidup masing-masing mendapat sepertiga bagian dan harta peninggalannya, bila yang mati itu hanya meninggalkan satu orang saudara laki-laki atau perempuan yang mendapat sisa yang sepertiga bagian. Bapak dan ibunya masing-masing mewarisi seperempat bagian, bila). yang mati meninggalkan lebih banyak saudara laki-laki atau perempuan, dan dalam hal itu mereka yang tersebut terakhir mendapat sisanya yang dua perempat bagian." (Pasal 854)

\section{${ }^{8}$ Ibid.}

${ }^{9}$ Ibid. 
Jika hanya ada orang tua, maka bapak dan ibu mendapatkan 1/2 bagian. Apabila hanya ada ahli waris bapak atau ibu saja maka bapak atau ibu yang hidup terlama tersebut mendapat seluruh harta peninggalan. Jika hanya ada seorang ibu atau bapak dan seorang saudara laki-laki atau perempuan, maka bapak atau ibu itu mendapat $1 / 2$ bagian dan bila ada dua orang saudara perempuan maka ia mendapat $1 / 3$ dan bila ada tiga atau lebih saudara laki-laki atau perempuan, maka ia mendapat $1 / 6$ bagian. (Pasal 855). ${ }^{10}$

"Bila seseorang meninggal tanpa meninggalkan seorang keturunan ataupun suami dan isteri, sedangkan bapak dan ibunya telah meninggal lebih dahulu, maka saudara laki-laki dan perempuan mewarisi seluruh warisannya."

(Pasal 856)

Apabila bagian orang tua sudah ditentukan, maka sisanya dibagi antara saudara laki-laki atau perempuanuntuk bagian yang sama, bila semuanya itu saudara sekandung atau semuanya sebapak atau seibu. Apabila saudara-saudara itu dari perkawinan yang berbeda, maka sisanya harta peninggalan setelah dikurangi dibagi menjadi dua, sebagian untuk garis bapak dan sebagian untuk garis ibu. ${ }^{11}$

Seperti yang telah dijelaskan sebelumnya, bahwa saudara kandung akan mendapatkan seluruh harta warisan apabila tidak ada ahli waris lainnya (Pasal 856). Saudara kandung akan mendapat harta warisan setelah dikurangi bagian ibu dan/atau ayah (Pasal 854 dan 855). Sesama saudara kandung, harta warisan dibagi sama rata. ${ }^{12}$ Mengenai hal yang mengatur perihal saudara seayah atau seibu (lain ayah atau lain ibu) diatur dalam pasal 857 KUH Perdata yang berbunyi : "Pembagian dan apa yang menurut

\footnotetext{
${ }^{10}$ Ibid., h. 30.

11 Ibid., h. 31

${ }^{12}$ Ibid., h. 33.
} 
pasal-pasal tersebut di atas menjadi bagian saudara perempuan dan laki-laki, dilakukan antara mereka menurut bagian-bagian yang sama, bila mereka berasal dan perkawinan yang sama; bila mereka dilahirkan dan berbagai perkawinan, maka apa yang mereka warisi harus dibagi menjadi dua bagian yang sama, antara garis bapak dengan garis ibu dan orang dan orang yang meninggal itu; saudara-saudara sebapak seibu memperoleh bagian mereka dan kedua garis, dan yang sebapak saja atau yang seibu saja hanya dan garis di mana mereka termasuk. Bila hanya ada saudara tiri laki-laki atau perempuan dan salah satu garis saja, mereka mendapat seluruh harta peninggalan, dengan mengesampingkan semua keluarga sedarah lainnya dan garis yang lain."

Ahli Waris Golongan III

Ahli waris golongan ke-III ini, yaitu keluarga sedarah dalam garis lurus ke atas jika si pewaris tidak meninggalkan keturunan maupun suami atau istri, orang tua, saudara-saudara atau keturunan saudara-saudara, maka yang mendapat giliran adalah keluarga sedarah selanjutnya di dalam garis lurus ke atas. ${ }^{13}$

\section{Ahli Waris Golongan IV}

Terdiri dari keluarga lainnya dari garis menyamping, yang dibatasi hanya sampai keturunan keenam, maupun dari pihak ayah maupun pihak ibu. ${ }^{14}$ Sedangkan dalam hukum kewarisan islam penentuan ahli waris diatur pada pasal 174 Kompilasi Hukum Islam (KHI):

1. Menurut hubungan darah terdiri dari :

a. Golongan laki-laki : ayah, anak laki-laki, saudara laki-laki, paman dan kakek.

b. Golongan perempuan : ibu, anak perempuan, saudara perempuan, dan nenek.

2. Menurut hubungan perkawinan yaitu janda dan duda.

\footnotetext{
${ }^{13}$ Ibid., h. 37.

${ }^{14}$ Ibid, h. 38.
} 
3. Apabila semua ahli waris ada, maka yang berhak mendapat warisan hanya anak, ayah, ibu, janda, duda.

Untuk besarnya bagian diatur dalam pasal 176-182 KHI (Kompilasi Hukum Islam) yaitu:

1. Bila hanya terdapat satu orang anak perempuan, ia mendapatkan $1 / 2$ bagian. Bila ada dua orang atau lebih, masing-masing mendapatkan 2/3 bagian. Apabila anak perempuan bersama-sama dengan anak laki-laki, maka anak laki-laki mendapatkan bagian dua banding satu dengan anak perempuan. (Pasal $176 \mathrm{KHI})$

2. Ayah mendapat $1 / 3$ bagian jika si pewaris tidak memiliki anak, jika memiliki anak, ayah mendapat bagian 1/6 dari harta warisan. (Pasal 177 $\mathrm{KHI})$

3. Ibu mendapat $1 / 6$ bagian bila ada anak, jika tidak ada anak ibu mendapat $1 / 3$ bagian. (178 KHI)

4. Duda mendapat $1 / 2$ bagian jika si pewaris tidak meninggalkan anak, jika si pewaris memiliki anak, maka duda mendapat 1/4 bagian (Pasal 179 KHI). Sedangkan janda, mendapatkan 1/8 bagian jika meninggalkan anak dan mendapatkan $1 / 4$ bagian jika tidak meninggalkan anak. (Pasal $180 \mathrm{KHI})$

5. Saudara (laki-laki dan perempuan) seibu masing-masing mendapat $1 / 6$ bagian jika si pewaris ttidak meninggalkan anak. Bila terdapat dua atau lebih saudara, masing-masing mendapatkan 1/3 bagian. (Pasal 181 KHI)

6. Bila si pewaris meninggal tanpa meninggalkan orang tua dan anak, tetapi ia memiliki satu orang saudara perempuan, maka ia mendapat $1 / 2$ bagian. Jika ia bersama-sama dengan saudara perempuan lainnya (sekandung/seayah), maka masing masing mendapat dua pertiga bagian. Bila saudara perempuan tersebut bersama-sama dengan saudara 
laki laki, maka bagian saudara laki-laki mendapat bagian dua berbanding satu dengan saudara perempuan. (Pasal 182 KHI)

Dalam sistem kewarisan adat dikenal sistem kewarisan matrilineal, patrilineal dan bilateral atau parental dalam hal ahli waris. ${ }^{15}$ Hal tersebut dapat diuraikan sebagai berikut :

a. Sistem matrilineal, yaitu sistem pewarisan yang menarik garis keturunan dari ibunya, seterusnya keatasnya kepada ibunya ibu sampai kepada sorang wanita yang dianggap sebagai marganya, di mana klan ibunya berasal dari keturunannya. ${ }^{16}$

b. Sistem patrilineal, yaitu sistem kewarisan yang berlawanan dari sistem patrilineal, sistem ini menarik garis keturunan dan hanya menghubungkan dirinya kepada ayahnya, ke atas kepada ayahnya ayah. 17

c. Sistem bilateral atau parental yaitu dimana setiap orang menghubungkan dirinya dalam hal keturunan baik kepada ibunya maupun ayahnya. ${ }^{18}$

\section{a. Syarat Terjadinya Pewarisan}

Ada tiga syarat terjadinya pewarisan, yaitu :

1. Adanya orang meninggal dunia.

Menurut pasal 830 KUH Perdata, pewarisan hanya berlangsung karena kematian. Ada beberapa pengecualian dalam pasal $830 \mathrm{KUH}$ Perdata antara lain orang yang dinyatakan meninggal dunia berdasarkan persangkaan, dianggap masih hidup. ${ }^{19}$ Namun bagi hukum ia merupakan orang yang sudah tiada sampai ditemukan bukti bahwa ia masih hidup. ${ }^{20}$

${ }^{15}$ Suparman, M. op.cit., h. 5.

${ }^{16}$ Ramulyo, M.I. (1993). Beberapa Masalah Pelaksanaan Hukum Kewarisan Perdata Barat (Burgelijk Wetboek). Jakarta: Sinar Grafika, h, 13-14.

${ }^{17}$ Suparman, M. op.cit., h.5.

${ }^{18}$ Ibid., h. 6,

${ }^{19}$ Ibid., h. 16

${ }^{20}$ Ibid. 
Lain halnya dengan sistem hukum pewarisan adat. Dalam sistem hukum pewarisan adat, proses pewarisan tidak ditentukan oleh kematian si pewaris, karena kematian adalah sebuah peristiwa yang pasti terjadi dan tidak dapat dihindari oleh siapapun. ${ }^{21}$ Maka dari itu kematian bukanlah penentu sebagaimana hukum Eropa atau Barat.

Jika dalam hukum kewarisan islam seperti yang tercantum dalam Kompilasi Hukum Islam (KHI) pasal 171 (b), pewaris adalah orang yang pada saat meninggalnya atau dinyatakan meninggal berdasarkan putusan Pengadilan, beragama Islam, meninggalkan ahli waris dan harta peninggalan. Dalam artian, meninggal seseorang (pewaris) ditentukan berdasarkan putusan pengadilan

2. Ada orang yang masih hidup, sebagai ahli waris yang akan memperoleh warisan pada saat pewaris meninggal dunia. ${ }^{22}$

Dalam hal menentukan ahli waris terdapat perbedaan antara yang tertuang dalam KUH Perdata dengan sistem hukum pewarisan adat. Menurut pasal 836 KUH Perdata, untuk dapat bertindak sebagai ahli waris ia hars ada saat harta peninggalan terbuka. Namun pada pasal $2 \mathrm{KUH}$ Perdata tertulis, anak yang ada dalam kandungan ibunya dianggap telah lahir, apabila kepentian si anak menghendakinya. Maka secara otomatis apabila bayi tersebut lahir hidup, ia berhak menerima bagian harta peninggalan ayahnya sama besar dengan ibu dan kakak-kakanya. 23 Dalam sistem hukum kewarisan adat, subyek pewarisan dibagi 2, yaitu :

- Orang tua yang menurunkan sejumlah harta benda kepada ahli warisnya. ${ }^{24}$

\footnotetext{
${ }^{21}$ Rato, D. (2015). Hukum Perkawinan dan Waris Adat di Indonesia (Sistem Kekerabatan, Perkawinan dan Pewarisan menurut Hukum Adat). Yogyakarta: LaksBang PRESSindo. h. 104

${ }^{22}$ Suparman, M. op.cit., h. 16

23 Ibid., h. 17

${ }^{24}$ Rato, D. op.cit., h.103
} 
- Ahli waris itu sendiri yaitu anak cucu yang berhak menerima harta benda sekaligus mempunyai kewajiban untuk meneruskannya kepada ahli waris berikutnya. ${ }^{25}$

3. Adanya harta kekayaan yang ditinggalkan ( harta warisan). ${ }^{26}$

Menurut KUH Perdata, dari manapun harta itu asalnya tetap merupakan satu kesatuan yang secara keseluruhan beralih dari tangan si pewaris kepada para ahli warisnya. Dengan demikian, dalam KUH Perdata tidak dikenal adanya harta bawaan, yaitu barang-barang yang dibawa oleh suami atau istri pada saat perkawinan dilangsungkan, pengecualiannya dilakukan dengan cara dibuat perjanjian kawin 27

Dalam sistem pewarisan hukum adat, harta yang dapat diwariskan dibagi menjadi dua, yaitu harta berwujud dan harta tidak berwujud. Harta yang berwujud misalnya seperti tanah, rumah, emas dan lain sebagainya yang bernilai uang dan jelas terlihat. Sedangkan harta yang tidak berwujud seperti gelar kebangsawanan, kehormatan keluarga dan status sosial lainnya. Jika dalam hukum perdata yang diwariskan adalah harta benda berwujud yang bernilai uang, lain halnya dengan sistem hukum adat. 28 Sedangkan dalam sistem kewarisan hukum islam ada yang dinamakan dengan harta bersama, namun tidak memungkiri adanya harta terpisah antara suami dengan istri. Seperti yang tercantum pada Pasal 85,86 dan 87 KHI :

Pasal 85

Adanya harta bersama dalam perkawinan itu tidak menutup kemungkinan adanya harta istri karena perkawinan.

Pasal 86

\footnotetext{
${ }^{25}$ Ibid.

${ }^{26}$ Suparman, M. op.cit., h. 16

${ }^{27}$ Ibid., h. 20

${ }^{28}$ Rato, D. op.cit., h.103
} 
(1) Pada dasarnya tidak ada percampuran antara harta suami dan harta istri karena perkawinan.

(2) Harta istri tetap menjadi hak istri dan dikuasai penuh olehnya, demikian juga dengan harta suami tetap menjadi hak suami dan dikuasai penuh olehnya.

Pasal 87

(1) Harta bawaan dari masing-masing suami dan istri dan harta yang diperoleh masing-masing sebagai hadiah atau warisan adalah di bawah penguasaan masing-masing, sepanjang para pihak tidak menentukan lain dalam perjanjian perkawinan.

(2) Suami dan istri mempunyai hak sepenuhnya untuk melakukan perbuatan hukum atas harta masing-masing berupa hibah, hadiah, sodaqah atau lainnya.

\section{b. Hubungan dan Kebutuhan Bisnis Terhadap Hukum Waris}

Bisnis dan Hukum Kewarisan sendiri memiliki kaitan yang sangat

erat. Pasalnya dalam menjalankan bisnis pasti menghasilkan harta kekayaan yang bisa dibilang tidak sedikit. Jika seorang pebisnis meninggal, lalu siapa yang akan melanjutkan bisnis yang telah dirintisnya tersebut. Disinilah gunanya hukum waris. Di dalam Hukum Waris telah diatur siapa yang berhak menjadi ahli waris beserta pembagian harta warisan bagi masing-masing ahli waris.

Namun, permasalahan hukum kewarisan ini bukanlah urusan sepele yang dapat dipandang sebelah mata. Sejak zaman dahulu urusan mengenai harta warisan ini selalu menimbulkan pertikaian bahkan dalam kasus tertentu dapat menimbulkan peperangan kecil. Pun saat ini yang hukum kewarisan sendiri telah diatur se-rinci mungkin didalam UndangUndang, baik itu dalam KUH Perdata, Kompilasi Hukum Islam (KHI), ataupun Hukum Adat, pertikaian dan peperangan kecil itu tidak dapat dihentikan, seperti telah melekat satu sama lain. 
Dahulu perang dunia membawa implikasi panjang terhadap sejarah hukum waris. Banyak para bangsawan yang meninggal dunia dalam peperangan dan meninggalkan harta warisan bernilai besar. Sulitnya lagi banyak diantara para bangsawan yang meninggal dunia tersebut tidak memiliki ahli waris, karena keluarga dan anak-anaknya ikut tewas di medan perang. Sehingga muncullah definisi harta warisan yang tidak dapat diwariskan. Hal tersebut yang menyebabkan pertikaian dari berbagai pihak untuk meperebutkan harta kekayaan yang terbengkalai tersebut. Perang dunia ini menyebabkan banyak kekayaan dan properti bernilai besar terbengkalai, bisnis yang mengalami kemunduran, sehingga bisa saja berpengaruh terhadap perekonomian dunia.

Saat harta kekayaan tersebut tidak jelas siapa pewarisnya, lantas siapa yang berhak memegang tanggung jawab atas harta kekayaan tersebut? jika harta warisan tersebut tidak memiliki ahli waris atau tidak ditemukan siapa yang berhak mewarisinya dalam kurun waktu tertentu, maka harta kekayaan tersebut jatuh kepada lembaga pemerintahan, hingga ditemukan ahli waris yang sah.

\section{c. Hubungan dan Kebutuhan Pilihan Karir dan Program Studi}

Awal saya memilih program studi hukum, saya belum memiliki target akan jadi apa saya nanti ketika mendapatkan gelar Sarjana Hukum. Tetapi setelah mendapatkan materi mengenai Advokat atau sedikitnya saya agak tertarik dengan profesi ini. Pelan-pelan saya mulai mempelajari mengenai profesi advokat dan semakin tertarik. Mungkin saat ini saya menspesifikasikan profesi tersebut sebagai Hukum Waris, karena saat ini saya juga tertarik dengan cabang ilmu hukum tersebut.

Bukan hal yang mudah memang menjadi seorang, terlebih lagi menjadi seorang hukum waris. Tanggung jawab yang diemban seorang sangat besar, tanggung jawab terhadap dirinya sendiri, juga terhadap kliennya. Saat ini tidak sedikit para yang justru melanggar kode etik yang 
telah ditetapkan. Dimana ia melakukan pekerjaannya semata-mata hanya untuk medapatkan materi bukan demi tegaknya hukum. Dalam kasus ini, hukum waris, telah banyak berkeliaran para heir hunters, sebutan untuk para pemburu harta warisan. Heir hunters sama seperti detektif, tetapi disini mereka merupakan seorang lawyer yang mencari ahli waris dari harta kekayaan yang ditinggalkan tanpa wasiat. Disini heir hunters akan mencari pewarisnya. Siapa pun itu, yang masih jadi keturunan atau kerabat jauh. Lalu mereka akan meminta bagian dari harta tersebut, 20\%,40\% atau dalam kasus yang lebih rumit mereka bisa memperoleh bagian yang lebih besar dari ahli warisnya sendiri. Hal yang dilakukan oleh para heir hunters ini telah melanggar kode etik seorang advokat, juga menjadi salah satu contoh tercorengnya nama baik seorang advokat atau yang seharusnya menegakkan hukum, dimata masyarakat awam.

Saya pernah meminta pendapat kepada beberapa orang yang saya temui mengenai pandangan mereka tentang . Banyak dari mereka yang menjawab, bahwa merupakan orang yang membela orang bersalah. Suka mencari-cari kesalahan orang lain dan sebagainya. Padahal sebenarnya profesi seorang sangatlah mulia, yaitu menegakkan hukum, menolong serta membantu mereka yang tertindas oleh para orang kaya yang hobi memainkan hukum menggunakan uang.

\section{d. Kelebihan, Kekurangan dan Tantangan Dari Pilihan Cabang Ilmu Hukum}

Seperti cabang ilmu hukum lainnya, hukum waris, sebagai cabang ilmu hukum juga memiliki tingkat kesulitannya sendiri. Mungkin itu dalam pemahaman materinya ataupun dalam menyelesaikan masalahnya. Karena seperti yang kita tahu, bahwa dalam ilmu hukum, praktek dan teorinya bisa saja sangat bertolak belakang. Seperti misalnya dalam kasus ini, seseorang meninggal dengan meninggalkan wasiat dengan tujuan agar harta kekayaan yang dimilikinya tidak menjadi perebutan diantara para 
ahli warisnya. Walaupun masalah wasiat dan ahli waris ini sudah diatur dalam Undang-Undang, namun tidak menjamin bahwa masalah selesai hanya dengan melihat peraturan yang ada di Undang-Undang. Masih banyak sekali kasus yang berakhir dengan peperangan kecil di pengadilan karena masalah wasiat ini. Ada saja pihak keluarga yang tidak setuju dengan ketentuan yang ada didalam wasiat. Hal-hal seperti itulah yang harus dipahami lebih dulu sebelum terjun ke dunia kerja.

Banyak skandal dalam usaha pencarian ahli waris, mulai dari penipu, impostor, hingga intrik hukum tingkat tinggi. Jika dimisalkan dengan sesuatu, masalah harta waris ini sama seperti gunung es didalam lautan, hanya atasnya saja yang terlihat, dibawahnya tidak akan ada yang tahu. Hal seperti ini melibatkan uang yang tidak sedikit nilainya, dan tentu saja mengundang 'lalat' mendekat.

Saat ini kehidupan modern menjadi suatu tantangan tersendiri bagi hukum waris untuk menemukan ahli waris yang sah. Karena, percaya atau tidak saat ini semua orang lebih mengandalkan teknologi ketimbang berbicara langsung kepada anggota keluarganya yang lain. Surat menyurat bukan lagi hal yang wajar di era modern seperti saat ini. Surat menyurat diganti dengan hal yang lebih mudah, seperti menggunakan media sosial, email, nomor HandPhone dan lain sebagainya. Hal seperti inilah yang bisa menimbulkan peperangan kecil diantara keluarga yang merasa dirinya pantas mendapatkan harta warisan, padahal saling berbicara pun tidak.

Namun hal-hal seperti itu menjadi tantangan tersendiri dalam memahami hukum waris ini. Tingkat kesulitan dan petualangan yang di tawarkan sedikit berbeda dengan cabang ilmu hukum lainnya. Jika bekerja sebagai legal officer disuatu perusahaan besar, kita lebih sering berhadapan dengan layar komputur daripada turun langsung menyelesaikan suatu kasus. Dalam masalah penyelesaian hukum waris ini, kita dituntut untuk mengetahui seluk-beluk kehidupan si pewaris hingga harus mengenal 
anggota keluarganya, bahkan juga kerabatnya. Bahkan dalam kasus tertentu seorang hukum waris dituntut untuk menelusuri kehidupan si pewaris terlebih dahulu sebelum menentukan siapa ahli waris yang sah.

Semenjak saya mempelajari hal-hal yang berkaitan dengan hukum waris ini sedikitnya saya mengetahui apa yang harus dilakukan ketika menghadapi masalah kewarisan didalam lingkup kecil, seperti di dalam keluarga sendiri. Kelebihan dari hukum waris ini adalah siapapun yang menghadapi kasus mengenai masalah kewarisan ini, ia mendapatkan sedikit gambaran mengenai hukum kewarisan. Setidaknya ia mengetahui siapa saja kah yang berhak menjadi ahli warisnya ketika ia meninggal dunia dan meninggalkan harta kekayaan.

\section{e. Kepemilikan Harta Dalam Islam}

Sebelum berbicara mengenai kewarisan Islam, perlu untuk diketahui mengenai perolehan/peralihan hak mili berdasarkan hukum Islam atau ajaran agama Islam

Menurut pandangan Islam hak milik dibedakan dan dibagi menjadi (3) tiga kelompok, yaitu: hak milik pribadi, hak milik umum, dan hak milik negara.

1. Kepemilikan Individu (Private Property)

Kepemilikan individu adalah ketetapan hukum syara' yang berlaku bagi dzat ataupun manfaat (jasa) tertentu, yang memungkinkan siapa saja yang mendapatkannya untuk memanfaatkan barang tersebut, individu memiliki hak untuk memiliki harta10 serta memperoleh kompensasi jika barangnya diambil kegunaannya oleh orang lain seperti disewa, ataupun karena dikonsumsi untuk dihabiskan dzatnya. Sebab-sebab kepemilikan tersebut terbatas pada lima sebab berikut ini:
a. Bekerja,
b. Warisan
c. Kebutuhan akan harta untuk menyambung hidup,
d. Harta pemberian negara yang diberikan kepada rakyat, 
e. Harta-harta yang diperoleh oleh seseorang dengan tanpa mengeluarkan harta atau tenaga apapun

Setiap individu memiliki hak untuk menikmati hak miliknya, menggunakannya secara produktif, memindahkannya dan melindunginya dari pemubaziran. Namun pemilik juga terkena sejumlah kewajiban tertentu, seperti membantu dirinya sendiri dan kerabatnya serta membayar sejumlah kewajiban.

2. Kepemilikan Umum (Collective Property)

Kepemilikan umum adalah izin Syari' kepada suatu komunitas untuk sama-sama memanfaatkan benda. Sedangkan benda-benda yang termasuk dalam kategori kepemilikan umum adalah benda-benda yang telah dinyatakan oleh Allah SWT dan Rasulullah SAW bahwa benda-benda tersebut untuk suatu komunitas dimana mereka masingmasing saling membutuhkan. Berkaitan dengan pemilikan umum ini, hukum Islam melarang benda tersebut dikuasai hanya oleh seseorang saja. Atas dasar pengertian di atas maka benda-benda yang termasuk dalam kepemilikan umum dapat dikelompokkan menjadi tiga kelompok:

Pertama, Benda-benda yang merupakan fasilitas umum. Bentuk fasilitas umum adalah apa saja yang dianggap sebagai kepentingan manusia secara umum. Rasulullah SAW telah menjelaskan dalam sebuah hadits bagaimana sifat fasilitas umum tersebut.

Kedua, Bahan tambang yang jumlahnya sangat besar. Bahan tambang dapat diklasifikasikan menjadi dua, yaitu: Barang tambang yang sedikit (terbatas) jumlahnya termasuk milik pribadi, serta boleh dimiliki secara pribadi, dan terhadap bahan tambang tersebut diberlakukan hukum rikaz (barang temuan), yang darinya harus dikeluarkan khumus, yakni seperlima bagiannya (20\%). Adapun bahan tambang yang sangat banyak (hampir tidak terbatas) jumlahnya, 
yang tidak mungkin dihabiskan oleh individu, maka bahan tambang tersebut termasuk milik umum (collective property), dan tidak boleh dimiliki secara pribadi.

Ketiga, Benda-benda yang sifat pembentukannya menghalangi untuk dimiliki oleh individu secara perorangan. Benda yang dapat dikategorikan sebagai kepemilikan umum yaitu jalan raya, sungai, masjid dan fasilitas umum lainnya. Benda-benda ini dari merupakan fasilitas umum dan hampir sama dengan kelompok pertama. Namun meskipun benda-benda tersebut seperti jenis yang pertama, tetapi berbeda dari segi sifatnya, bahwa benda tersebut tidak bisa dimiliki oleh individu. Barang-barang kelompok pertama dapat dimiliki oleh individu jika jumlahnya kecil dan tidak menjadi sumber kebutuhan suatu komunitas. Misalnya sumur air, mungkin saja dimiliki oleh individu, namun jika sumur air tersebut dibutuhkan oleh suatu komunitas maka individu tersebut dilarang memilikinya. Berbeda dengan jalan raya, mesjid, sungai dan lain-lain yang memang tidak mungkin dimiliki oleh individu.

3. Kepemilikan Negara (State Property)

Harta-harta yang termasuk milik negara adalah harta yang merupakan hak seluruh kaum muslimin yang pengelolaannya menjadi wewenang negara, di mana negara dapat memberikan kepada sebagian warga negara, sesuai dengan kebijakannya. Makna pengelolaan oleh negara ini adalah adanya kekuasaan yang dimiliki negara untuk mengelolanya semisal harta fai, kharaj, jizyah dan sebagainya. Meskipun harta milik umum dan milik negara pengelolaannya dilakukan oleh negara, namun ada perbedaan antara kedua bentuk hak milik tersebut. Harta yang termasuk milik umum pada dasamya tidak boleh diberikan negara kepada siapapun, meskipun negara dapat membolehkan kepada orang-orang untuk mengambil dan 
memanfaatkannya. Berbeda dengan hak milik negara di mana negara berhak untuk memberikan harta tersebut kepada individu tertentu sesuai dengan kebijakan negara. Harta kekayaan sejatinya adalah milik Allah SWT.

Dengan begitu, berarti harta kekayaan memiliki fungsi sosial yang tujuannya adalah kesejahteraaan masyarakat dan memenuhi kebutuhankebutuhan serta kemaslahatan-kemaslahatannya. Jadi dengan begitu,kepemilikan individu di dalam pandangan Islam merupakan sebuah fungsi sosial. Syaikh Abu Zahrah berpandangan, bahwa tidak ada halangan untuk mengatakan bahwa kepemilikan adalah fungsi sosial. Akan tetapi harus diketahui bahwa itu harus berdasarkan ketentuan Allah SWT bukan ketentuan para hakim, karena mereka tidaklah selalu orang-orang yang adil.

\section{f. Hukum Kewarisan Islam}

Hukum kewarisan Islam mengatur peralihan harta dari seseorang yang telah meninggal kepada yang masih hidup. Aturan tentang peralihan harta ini disebut dengan berbagai nama. Dalam literatur hukum Islam ditemukan beberapa istilah untuk menamakan hukum kewarisan seperti seperti: Faraid, Fiqih Mawaris, dan hukmal-Waris. Perbedaan dalam penamaan ini terjadi karena perbedaan arah yang dijadikan titik utama dalam pembahasan. Namun kata yang lazim dipakai adalah faraid sebagaimana digunakan oleh an-Nawawi dalam kitab Mihaj alThalibin.

Pengertian Hukum waris Islam berdasarkan Kompilasi Hukum Islam adalah hukum yang mengatur tentang pemindahan hak pemilikasn harta peninggalan (tirkah) pewaris, menentukan siapa-siapa yang berhak menjadi ahli waris dan berapa bagiannya masing-masing.

Pada dasarnya waris dalam Islam merupakan suatu yang tak terpisahkan, oleh karena itu, untuk mengaktualisasikan dalam Islam, maka eksistensinya harus dijabarkan dalam bentuk faktual. Dalam hal ini, 
pelaksanaan hukum kewarisan harus kelihatan dalam sistem keluarga yang berlaku dalam masyarakat. Dari seluruh hukum yang berlaku dalam masyarakat, maka hukum perkawinan dan kewarisan yang menentukan dan mencerminkan sistem kekeluargaan yang sekaligus merupakan salah satu bagian dari hukum perdata.

Dari seluruh hukum yang ada dan berlaku dewasa ini di samping hukum perkawinan, maka hukum kewarisan merupakan bagian dari hukum kekeluargaan yang memegang peranan yang sangat penting, bahkan menentukan dan mencerminkan sistem dan bentuk hukum yang berlaku dalam masyarakat.Hal ini, disebabkan hukum kewarisan itu sangat erat kaitannya dengan ruang lingkup kehidupan manusia bahwa setiap manusia pasti akan mengalami peristiwa, yang merupakan peristiwa hukum yang lazim yang disebut meninggal dunia.

Wujud warisan atau harta peninggalan menurut Hukum Islam sangat berbeda dengan wujud warisan menurut hukum barat sebagai mana diatur dalam KUHPerdata maupun hukum waris adat.Warisan atau harta peninggalan menurut hukum Islam yaitu "sejumlah harta benda serta segala hak dari yang meninggal dunia dalam keadaan bersih". Artinya harta peninggalan yang diwarisi oleh para ahli waris adalah sejumlah harta benda serta segala hak, "setelah dikurangi dengan pembayaran hutanghutang pewaris dan pembayaran-pembayaran lain yang diakibatkan oleh wafatnya sipeninggal waris"

Bahwa berdasarkan ketentuan Pasal 584 mengenai beralihnya hak milik dapat terjadi salah satunya karena pewarisan jo. Pasal 830 KUHPerdata "Pewarisan hanya terjadi karena apabila ada kematian". Apabila belum ada kematian maka belum terjadi warisan. Wiryono Prodjodikoro mengatakan: "warisan adalah soal apakah dan bagaimanakah pelbagai hak-hak dan kewajiban-kewajiban tentang kekayaan seseorang pada waktu ia meninggal dunia akan beralih kepada orang lain yang masih hidup." 
Di sini dapat diartikan bahwa pewarisan akan berlangsung apabila pewaris sudah meninggal dunia dan pewaris meninggalkan harta warisan.

\section{g. Asas-Asas Hukum Kewarisan Islam}

Hal-hal yang berkaitan dan menyangkut asas-asas hukum kewarisan Islam dapat digali dari ayat-ayat hukum kewarisan serta Hadits/Sunah nabi Muhammad SAW.

Asas-asas tersebut dapat diklasifikasikan sebagai berikut:

a. Asas Ijbari

Secara etimologi "Ijbari" mengandung arti paksaan, yaitu melakukan sesuatu di luar kehendak sendiri. Dalam hal hukum waris berarti terjadinya peralihan harta seseorang yang telah meninggal kepada yang masih hidup terjadi dengan sendirinya. Artinya tanpa adanya perbuatan hukum atau pernyataan kehendak dari pewaris. Dengan perkataan lain adanya kematian pewaris secara otomatis hartanya beralih kepada ahli warisnya.

Asas Ijbari ini dapat dilihat dari berbagai segi yaitu:

1. dari peralihan harta;

2. dari segi jumlah harta yang beralih;

3. dari segi kepada siapa harta itu akan beralih.

Ketentuan mengenai Asas Ijbari ini dapat dilihat antara lain dalam ketentuan Al-Qur'an, surat An-Nisa ayat 7 yang menyelaskan bahwa: bagi seorang laki-laki maupun perempuan ada nasib dari harta peninggalan orang tuanya atau dari karib kerabatnya, kata nasib dalam ayat tersebut dalam arti saham, bagian atau jatah dari harta peninggalan si pewaris.

b. Asas Bilateral

Yang dimaksud dengan asas bilateral dalam hukum kewarisan Islam adalah seseorang menerima hak kewarisan bersumber dari kedua belah 
pihak kerabat, yaitu dari garis keturunan perempuan maupun keturunan laki-laki.

Ketentuan mengenai Asas bilateral ini secara tegas dapat dilihat dalam ketentuan Al-Qur'an surat An-Nisa ayat 7, 11, 12 dan 176, antara lain dalam ayat 7 dikemukakan bahwa seorang laki-laki berhak memperoleh warisan dari pihak ayahnya maupun ibunya. Begitu juga dengan perempuan mendapat warisan dari kedua belah pihak orang tuanya. Asas bilateral ini juga berlaku pula untuk kerabat garis ke samping (yaitu melalui ayah dan ibu).

c. Asas Individual

Pengertian asas individual ini adalah: setiap ahli waris (secara individu) berhak atas bagian yang didapatkan tanpa terikat kepada ahli waris lainnya. Dengan demikian bagian yang diperoleh oleh ahli waris secara individu berhak mendapatkan semua harta yang telah menjadi bagiannya. Ketentuan ini dapat dijumpai dalam ketentuan Al-Qur'an surat An-Nisa ayat 7 yang mengemukakan bahwa bagian masingmasing ahli waris ditentukan secara individu.

d. Asas Keadilan Berimbang Asas keadilan berimbang maksudnya adalah keseimbangan antara hak dengan kewajiban dan keseimbangan antara yang diperoleh dengan kebutuhan dan kegunaan. Dengan perkataan lain dapat dikemukakan bahwa faktor jenis kelamin tidak menentukan dalam hak kewarisan. Dasar hukum asas ini adalah dalam ketentuan Al-Qur'an surat An-Nisa ayat $7,11,12$ dan 179 .

e. Kewarisan Akibat Kematian

Hukum waris Islam memandang bahwa terjadinya peralihan harta hanya semata-mata karena adanya kematian. Dengan perkataan lain harta seseorang tidak dapat beralih apabila belum ada kematian. 
Apabila pewaris masih hidup maka peralihan harta tidak dapat dilakukan dengan pewarisan.

f. Asas Tandhidh

Asas tandhidh kelihatannya layak untuk dipertimbangkan dalam pembagian harta warisan, terutama terhadap mauruts/tirkah yang ragam dari segi bentuk dan nilai.

\section{Kesimpulan}

Permasalahan mengenai hukum kewarisan ini selalu saja memiliki tantangannya sendiri di dalam setiap kasusnya. Mulai dari yang mudah ditangani hingga kasus yang sampai meninmbulkan peperangan kecil diantara keluarga, bahkan kadang ada pula para lawyer yang mencari keuntungan dari kasus hukum waris ini. yang sering mencari keuntungan untuk dirinya sendirinya inilah yang kadang membuat masyarakat memiliki perspektif buruk dalam benak mereka mengenai profesi, yang seharusnya merupakan profesi yang sangat mulia. Baiknya, agar keluarga dari si pewaris taat pada hukum dalam masalah pembagian warisan, tidak perlu sampai memperebutkan harta yang jelas-jelas sudah dibagikan sesuai dengan ketentuan huku. Dengan begitu perkara hukum kewarisan ini menjadi lebih mudah untuk diselesaikan.

\section{DAFTAR PUSTAKA}

Marzuki, P.M. (2010). Penelitian Hukum, Jakarta: Kencana Prenada.

Ramulyo, M.I. (1993). Beberapa Masalah Pelaksanaan Hukum Kewarisan Perdata Barat (Burgelijk Wetboek). Jakarta: Sinar Grafika 
Rato, D. (2015). Hukum Perkawinan dan Waris Adat di Indonesia (Sistem Kekerabatan, Perkawinan dan Pewarisan menurut Hukum Adat). Yogyakarta: LaksBang PRESSindo.

Soekanto, S. \& Mamudji, S. (2003). Penelitian Hukum Normatif : Suatu Tinjauan Singkat. Jakarta: Raja Grafindo Persada

Suparman,M. (2015). Hukum Waris Perdata. Jakarta: Sinar Grafika. (2005). Hukum Waris Indonesia dalam Perspekstif Islam, Adat dan $B W$. Bandung: Refika Aditama. 